\title{
Uniform requirements for manuscripts submitted to biomedical journals
}

\author{
International Committee of Medical Journal Editors
}

In January 1978 a group of editors from some major biomedical journals published in English met in Vancouver, British Columbia, and decided on uniform technical requirements for manuscripts to be submitted to their journals. These requirements, including formats for bibliographic references, were published in three of the journals early in 1979. The Vancouver group evolved into the International Committee of Medical Journal Editors. At the October 1981 meeting of the committee the requirements were revised slightly and are presented as the main part of this document.

Over 150 journals have now agreed to receive manuscripts prepared in accordance with these requirements. It is important to emphasise what these requirements imply and what they do not.

Firstly, if authors prepare their manuscripts in the style specified in these requirements, editors will not return manuscripts for changes in details of style, Even so, manuscripts may be altered by journals to conform with details of their own publication styles.

Thus, secondly, the requirements are instructions to authors on how to prepare manuscripts, not to editors on publication style.

Thirdly, authors sending manuscripts to a participating journal should not try to prepare them in accordance with the individual publication style of that journal but should follow the "Uniform requirements for manuscripts submitted to biomedical journals."

Nevertheless, authors must also follow the instructions to authors in the journal as to what topics are suitable for that journal and the types of papers that may be submitted-for example, original articles, reviews, case reports. In addition, the journal's instructions are likely to contain other requirements unique to that journal, such as number of copies of manuscripts, acceptable languages, length of articles, and approved abbreviations besides those listed in this document.

The co-operating journals are expected to state in their instructions to authors that their requirements are in accordance with "Uniform requirements for manuscripts submitted to biomedical journals."

This document will be revised at intervals. Inquiries and comments from Central and North America about these requirements should be sent to Edward J Huth, MD, Annals of Internal Medicine, 4200 Pine Street, Philadelphia, PA 19104,

Members of the Committee are: Ole Harlem (Norwegian Medical fournal) Edward J Huth (Annals of Internal Medicine), Stephen Lock (British Medical Fournal), Ian Munro (Lancet), Arnold Relman (New England fournal of Medicine), Povl Riis (Danish Medical Bulletin), Richard Robinson (New Zealand Medical fournal), Andrew Sherrington (Canadian Medical Association fournal), Therese Southgate (fournal of the American Medical Association), Ilkka Vartiovaara (Finnish Medical fournal).
USA; those from other regions should be sent to Stephen Lock, FRCP, British Medical fournal, British Medical Association, Tavistock Square, London WC1H 9JR, United Kingdom.

Editors of journals which have agreed to accept manuscripts that conform to the uniform requirements may reprint this article, and single reprints will be available to editors free of charge if they send a stamped addressed envelope and to authors at a cost of $70 \mathrm{p}$ (including postage).

\section{Summary of requirements}

Type the manuscript double spaced, including title page, abstract, text, acknowledgments, references, tables, and legends.

Each manuscript component should begin on a new page, in this sequence: title page; abstract and key words; text; acknowledgments; references; tables: each table, complete with title and footnotes, on a separate page; legends for illustrations.

Illustrations must be good quality, unmounted glossy prints usually $127 \times 173 \mathrm{~mm}(5 \times 7$ in) but no larger than $203 \times 254 \mathrm{~mm}$ $(8 \times 10$ in $)$.

Submit the required number of copies of manuscript and figures (see journal's instructions) in a heavy-paper envelope. The submitted manuscript should be accompanied by a covering letter, as described under "Submission of manuscripts," and permissions to reproduce previously published materials or to use illustrations that may identify human subjects.

Follow the journal's instructions for transfer of copyright. Authors should keep copies of everything submitted.

\section{Prior and duplicate publication}

Most journals do not wish to consider for publication a paper on work that has already been reported in a published paper or is described in a paper submitted or accepted for publication elsewhere. This policy does not usually preclude consideration of a manuscript that has been rejected by another journal or of a complete report that follows publication of a preliminary report, usually in the form of an abstract. When submitting a manuscript an author should always make a full statement to the editor about all submissions and prior reports that might be regarded as prior or duplicate publication of the same or very similar work. Copies of such material should be included with the submitted manuscript to help the editor decide how to deal with the matter.

\section{Preparation of manuscript}

Type the manuscript on white bond paper, $216 \times 279 \mathrm{~mm}\left(8 \frac{1}{2} \times\right.$ 11 in) or ISO A4 $(212 \times 297 \mathrm{~mm})$, with margins of at least $25 \mathrm{~mm}$ ( 1 in). Type only on one side of the paper. Use double spacing 
throughout, including title page, abstract, text, acknowledgments, references, tables, and legends for illustrations. Begin each of the following sections on separate pages: title page, abstract and key words, text, acknowledgments, references, individual tables, and legends. Number pages consecutively, beginning with the title page. Type the page number in the upper righthand corner of each page.

\section{TITLE PAGE}

The title page should carry (1) the title of the article, which should be concise but informative; (2) a short running head or footline of no more than 40 characters (count letters and spaces) placed at the foot of the title page and identified; (3) first name, middle initial, and last name of each author, with highest academic degree(s); (4) name of department(s) and institution(s) to which the work should be atttibuted; (5) disclaimers, if any; (6) name and address of author responsible for correspondence about the manuscript; (7) name and address of author to whom requests for reprints should be addressed, or statement that reprints will not be available from the author; (8) the source(s) of support in the form of grants, equipment, drugs, or all of these.

\section{ABSTRACT AND KEY WORDS}

The second page should carry an abstract of no more than 150 words. The abstract should state the purposes of the study or investigation, basic procedures (study subjects or experimental animals; observational and analytical methods), main findings (give specific data and their statistical significance, if possible), and the principal conclusions. Emphasise new and important aspects of the study or observations. Use only approved abbreviations (see Commonly used approved abbreviations elsewhere in this document).

Below the abstract, provide, and identify as such, three to 10 key words or short phrases that will assist indexers in crossindexing your article and that may be published with the abstract. Use terms from the medical subject headings list from Index Medicus when possible.

\section{TEXT}

The text of observational and experimental articles is usually-but not necessarily-divided into sections with the headings Introduction, Methods, Results, and Discussion. Long articles may need subheadings within some sections to clarify their content, especially the Results and Discussion sections. Other types of articles such as case reports, reviews, and editorials are likely to need other formats, and authors should consult individual journals for further guidance.

Introduction-Clearly state the purpose of the article. Summarise the rationale for the study or observation. Give only strictly pertinent references, and do not review the subject extensively.

Methods-Describe your selection of the observational or experimental subjects (patients or experimental animals, including controls) clearly. Identify the methods, apparatus (manufacturer's name and address in parentheses), and procedures in sufficient detail to allow other workers to reproduce the results. Give references to established methods, including statistical methods; provide references and brief descriptions for methods that have been published but are not well known; describe new or substantially modified methods, give reasons for using them, and evaluate their limitations.

When reporting experiments on human subjects, indicate whether the procedures followed were in accordance with the ethical standards of the committee on human experimentation of the institution in which the experiments were done or in accordance with the Helsinki Declaration of 1975 . When reporting experiments on animals, indicate whether the institution's or the national research council's guide for the care and use of laboratory animals was followed. Identify precisely all drugs and chemicals used, including generic name(s), dosage(s), and route(s) of administration. Do not use patients' names, initials, or hospital numbers.

Include numbers of observations and the statistical significance of the findings when appropriate. Detailed statistical analyses, mathematical derivations, and the like may sometimes be suitably presented in the form of one or more appendixes.

Results-Present your results in logical sequence in the text, tables, and illustrations. Do not repeat in the text all the data in the tables, illustrations, or both: emphasise or summarise only important observations.
Discussion-Emphasise the new and important aspects of the study and conclusions that follow from them. Do not repeat in detail data given in the Results section. Include in the Discussion the implications of the findings and their limitations and relate the observations to other relevant studies. Link the conclusions with the goals of the study but avoid unqualified statements and conclusions not completely supported by your data. Avoid claiming priority and alluding to work that has not been completed. State new hypotheses when warranted, but clearly label them as such. Recommendations, when appropriate, may be included.

\section{ACKNOWLEDGMENTS}

Acknowledge only persons who have made substantive contributions to the study. Authors are responsible for obtaining written permission from everyone acknowledged by name because readers may infer their endorsement of the data and conclusions.

\section{REFERENCES}

Number references consecutively in the order in which they are first mentioned in the text. Identify references in text, tables, and legends by arabic numerals (in parentheses). References cited only in tables or in legends to figures should be numbered in accordance with a sequence established by the first identification in the text of the particular table or illustration.

Use the style of the examples below, which are based on the formats used by the US National Library of Medicine in Index Medicus.

The titles of journals should be abbreviated according to the style used in Index Medicus. A list of abbreviated names of frequently cited journals is given near the end of this document; for others, consult the "List of the Journals Indexed," printed annually in the January issue of Index Medicus.

Try to avoid using abstracts as references; "unpublished observations" and "personal communications" may not be used as references, although references to written, not verbal, communications may be inserted (in parentheses) in the text. Include among the references manuscripts accepted but not yet published; designate the journal followed by "in press" (in parentheses). Information from manuscripts submitted but not yet accepted should be cited in the text as "unpublished observations" (in parentheses).

The references must be verified by the author(s) against the original documents.

Examples of correct forms of references are given below.

\section{Fournals}

(1) Standard journal article-(List all authors when six or less; when seven or more, list only first three and add et al.) You CH, Lee KY, Chey WY, Menguy R. Electrogastrographic study of patients with unexplained nausea, bloating and vomiting. Gastroenterology 1980;79:311-4.

\section{(2) Corporate author}

The Royal Marsden Hospital Bone-Marrow Transplantation Team. Failure of syngeneic bone-marrow graft without preconditioning in post-hepatitis marrow aplasia. Lancet $1977 ; 2: 242-4$

\section{(3) No author given}

Anonymous. Coffee drinking and cancer of the pancreas [Editorial]. Br Med J 1981;283:628.

\section{(4) Fournal supplement}

Mastri AR. Neuropathy of diabetic neurogenic bladder. Ann Intern Med 1980;92(2 Pt 2):316-8.

Frumin AM, Nussbaum J, Esposito M. Functional asplenia: demonstration of splenic activity by bone marrow scan [Abstract]. Blood 1979;54(suppl 1):26a.

(5) Fournal paginated by issue

Seaman WB. The case of the pancreatic pseudocyst. Hosp Pract $1981 ; 16($ Sep $): 24-5$ 
Books and other monographs

(6) Personal author(s)

Eisen HN. Immunology: an introduction to molecular and cellular principles of the immune response. 5th ed. New York: Harper and Row, 1974:406.

(7) Editor, compiler, chairman as author

Dausset J, Colombani J, eds. Histocompatibility testing 1972. Copenhagen: Munksgaard, 1973:12-8.

(8) Chapter in a book

Weinstein L, Swartz MN. Pathogenic properties of invading microorganisms. In: Sodeman WA Jr, Sodeman WA, eds. Pathologic physiology: mechanisms of disease. Philadelphia W B Saunders, $1974 ; 457-72$.

(9) Published proceedings paper

DuPont B. Bone marrow transplantation in severe combined immunodeficiency with an unrelated MLC compatible donor. In: White HJ, Smith R, eds. Proceedings of the third annual meeting of the International Society for Experimental Hematology. Houston: International Society for Experimental Hematology, 1974:44-6.

(10) Monograph in a series

Hunninghake GW, Gadek JE, Szapiel SV, et al. The human alveolar macrophage. In: Harris CC ed. Cultured human cells and tissues in biomedical research. New York: Academic Press, 1980;54-6. (Stoner GD, ed. Methods and perspectives in cell biology; vol 1 ).

(11) Agency publication

Ranofsky AL. Surgical operations in short-stay hospitals: United States-1975. Hyattsville, Maryland: National Centre for Health Statistics, 1978; DHEW publication no. (PHS)78-1785. (Vital and health statistics; series 13; no 34).

\section{(12) Dissertation or thesis}

Cairns RB. Infrared spectroscopic studies of solid oxygen. Berkeley, California: University of California, 1965. 156 pp. Dissertation.

\section{Other articles}

\section{(13) Newspaper article}

Shaffer RA. Advances in chemistry are starting to unlock mysteries of the brain: discoveries could help cure alcoholism and insomnia, explain mental illness. How the messenger work. Wall Street Journal 1977 Aug 12:1(col 1), 10(col 1).

\section{(14) Magazine article}

Roueché B. Annals of medicine: the Santa Claus culture. The New Yorker 1971 Sep 4:66-81.

\section{TABLES}

Type each table on a separate sheet; remember to double space. Do not submit tables as photographs. Number tables consecutively and supply a brief title for each. Give each column a short or abbreviated heading. Place explanatory matter in footnotes, not in the heading. Explain in footnotes all non-standard abbreviations that are used in each table. For footnotes, use the following symbols, in this sequence: $*, \dagger, \ddagger, \S, \|, q, * *, \dagger \dagger \ldots$.

Identify statistical measures of variations such as SD and SEM.

Do not use internal horizontal and vertical rules.

Cite each table in the text in consecutive order.

If you use data from another published or unpublished source, obtain permission and acknowledge fully.

The use of too many tables in relation to the length of the text may produce difficulties in the layout of pages. Examine issues of the journal to which you plan to submit your manuscript to estimate how many tables can be used per 1000 words of text.

The editor on accepting a manuscript may recommend that additional tables containing important backup data too extensive to publish be deposited with the National Auxiliary Publications Service or made available by the author(s). In that event, an appropriate statement will be added to the text. Submit such tables for consideration with the manuscript.

\section{ILLUSTRATIONS}

Submit the required number of complete sets of figures. Figures should be professionally drawn and photographed; freehand or typewritten lettering is unacceptable. Instead of original drawings, roentgenograms, and other material, send sharp, glossy black-andwhite photographic prints, usually $127 \times 173 \mathrm{~mm}(5 \times 7$ in $)$ but no larger than $203 \times 254 \mathrm{~mm}(8 \times 10 \mathrm{in})$. Letters, numbers, and symbols should be clear and even throughout, and of sufficient size that when reduced for publication each item will still be legible. Titles and detailed explanations belong in the legends for illustrations, not on the illustrations themselves.

Each figure should have a label pasted on its back indicating the number of the figure, the names of the authors, and the top of the figure. Do not write on the back of the figures, mount them on cardboard, or scratch or mar them using paper clips. Do not bend figures.

Photomicrographs must have internal scale markers. Symbols, arrows, or letters used in the photomicrographs should contrast with the background.

If photographs of persons are used, either the subjects must not be identifiable or their pictures must be accompanied by written permission to use the photograph.

Cite each figure in the text in consecutive order. If a figure has been published, acknowledge the original source and submit written permission from the copyright holder to reproduce the material. Permission is required, regardless of authorship or publisher, except for documents in the public domain.

For illustrations in colour, supply colour negatives or positive transparencies and, when necessary, accompanying drawings marked to indicate the region to be reproduced; in addition, send two positive colour prints to assist editors in making recommendations. Some journals publish illustrations in colour only if the author pays for the extra cost.

\section{LEGENDS FOR ILLUSTRATIONS}

Type legends for illustrations double spaced, starting on a separate page, with arabic numerals corresponding to the illustrations. When symbols, arrows, numbers, or letters are used to identify parts of the illustrations, identify and explain each one clearly in the legend. Explain internal scale and identify method of staining in photomicrographs.

\section{Units of measurement}

Measurements of length, height, weight, and volume should be reported in metric units (metre, kilogram, litre) or their decimal multiples.

Temperatures should be given in degrees Celsius. Blood pressures should be given in millimetres of mercury. Other measurements should be reported in the units in which they were made.

In most countries the International System of Units (SI) is standard or is becoming so. Journals may use these units or convert them to other units according to their editorial policies. Editors may request that alternative units (SI or non-SI units) be added by the author before publication of the paper.

\section{Abbreviations and symbols}

Use only standard abbreviations (see below for lists of commonly used abbreviations). Consult the following sources for additional abbreviations: (1) CBE Style Manual Committee. Council of Biology Editors Style Manual: a Guide for Authors, Editors, and Publishers in the Biological Sciences. 4th ed. Arlington, Virginia: Council of Biology Editors, 1978; and (2) O'Connor M, Woodford FP. Writing Scientific Papers in English: an ELSE-Ciba Foundation Guide for Authors. Amsterdam: Elsevier-Excerpta Medica, 1975. Avoid abbreviations in the title. The full term for which an abbreviation stands should precede its first use in the text unless it is a standard unit of measurement. 
Commonly used approved abbreviations

Standard units of measurement, combining prefixes and statistical terms

\begin{tabular}{|c|c|c|c|c|c|}
\hline \multicolumn{2}{|r|}{ Term } & $\begin{array}{c}\text { Abbreviation } \\
\text { or symbol }\end{array}$ & & Term & $\begin{array}{c}\text { Abbreviation } \\
\text { or symbol }\end{array}$ \\
\hline \multicolumn{6}{|c|}{ Standard units of measurement } \\
\hline \multicolumn{2}{|c|}{$\begin{array}{l}\text { ampere } \\
\text { ángström } \\
\text { barn } \\
\text { candela } \\
\text { coulomb } \\
\text { counts per minute } \\
\text { counts per second } \\
\text { curie } \\
\text { degree Celsius } \\
\text { disintegration per } \\
\text { minute } \\
\text { disintegration per } \\
\text { second } \\
\text { electron Volt } \\
\text { equivalent } \\
\text { farad } \\
\text { gauss } \\
\text { gram } \\
\text { henry } \\
\text { hertz } \\
\text { hour }\end{array}$} & $\begin{array}{l}\mathrm{A} \\
\AA \\
\mathrm{b} \\
\mathrm{cd} \\
\mathrm{C} \\
\mathrm{cpm} \\
\mathrm{cps} \\
\mathrm{Ci} \\
{ }^{\circ} \mathrm{C} \\
\mathrm{dpm} \\
\mathrm{dps} \\
\mathrm{eV} \\
\mathrm{Eq} \\
\mathrm{F} \\
\mathrm{G} \\
\mathrm{g} \\
\mathrm{H} \\
\mathrm{Hz} \\
\mathrm{h}\end{array}$ & \multicolumn{2}{|c|}{$\begin{array}{l}\text { international unit } \\
\text { joule } \\
\text { kelvin } \\
\text { kilogram } \\
\text { liter, litre } \\
\text { meter, metre } \\
\text { minute } \\
\text { molar } \\
\text { mole } \\
\text { newton } \\
\text { normal (concentration) } \\
\text { ohm } \\
\text { osmol } \\
\text { pascal } \\
\text { revolutions per minute } \\
\text { second } \\
\text { square centimeter } \\
\text { volt } \\
\text { watt } \\
\text { week } \\
\text { year }\end{array}$} & $\begin{array}{l}\mathrm{IU} \\
\mathrm{J} \\
\mathrm{K} \\
\mathrm{kg} \\
\mathrm{lor} \mathrm{L} \\
\mathrm{m} \\
\mathrm{min} \\
M \\
\mathrm{~mol} \\
\mathrm{~N} \\
\mathrm{~N} \\
\Omega \\
\text { osmol } \\
\mathrm{Pa} \\
\mathrm{rpm} \\
\mathrm{s} \\
\mathrm{cm} \\
\mathrm{V} \\
\mathrm{W} \\
\mathrm{wk} \\
\mathrm{yr}\end{array}$ \\
\hline \multicolumn{6}{|c|}{ Combining prefixes } \\
\hline $\begin{array}{l}\text { tera- } \\
\text { giga- } \\
\text { mega- } \\
\text { kilo- } \\
\text { hecto- } \\
\text { deca- } \\
\text { deci- }\end{array}$ & $\begin{array}{l}\left(10^{12}\right) \\
\left(10^{9}\right) \\
\left(10^{6}\right) \\
\left(10^{3}\right) \\
\left(10^{2}\right) \\
\left(10^{1}\right) \\
\left(10^{-1}\right)\end{array}$ & $\begin{array}{l}\mathrm{T} \\
\mathrm{G} \\
\mathrm{M} \\
\mathrm{k} \\
\mathrm{h} \\
\mathrm{da} \\
\mathrm{d}\end{array}$ & $\begin{array}{l}\text { centi- } \\
\text { milli- } \\
\text { micro- } \\
\text { nano- } \\
\text { pico- } \\
\text { femto- } \\
\text { atto- }\end{array}$ & $\begin{array}{l}\left(10^{-2}\right) \\
\left(10^{-3}\right) \\
\left(10^{-6}\right) \\
\left(10^{-9}\right) \\
\left(10^{-12}\right) \\
\left(10^{-15}\right) \\
\left(10^{-18}\right)\end{array}$ & $\begin{array}{l}\mathrm{c} \\
\mathrm{m} \\
\mathrm{n} \\
\mathrm{p} \\
\mathrm{f} \\
\mathrm{a}\end{array}$ \\
\hline \multicolumn{6}{|c|}{ Statistical terms } \\
\hline \multicolumn{2}{|c|}{$\begin{array}{l}\text { correlation coefficient } \\
\text { degrees of freedom } \\
\text { mean } \\
\text { not significant } \\
\text { number of observations } \\
\text { probability }\end{array}$} & $\begin{array}{l}\mathrm{r} \\
\mathrm{df} \\
\overline{\mathrm{x}} \\
\mathrm{N} S \\
\mathrm{n} \\
\mathrm{p}\end{array}$ & \multicolumn{2}{|c|}{$\begin{array}{l}\text { standard deviation } \\
\text { standard error of the } \\
\text { mean } \\
\text { "Student's"' } t \text { test } \\
\text { variance ratio }\end{array}$} & $\begin{array}{l}\text { SD } \\
\text { SEM } \\
t \text { test } \\
\mathrm{F}\end{array}$ \\
\hline
\end{tabular}

Other common abbreviations

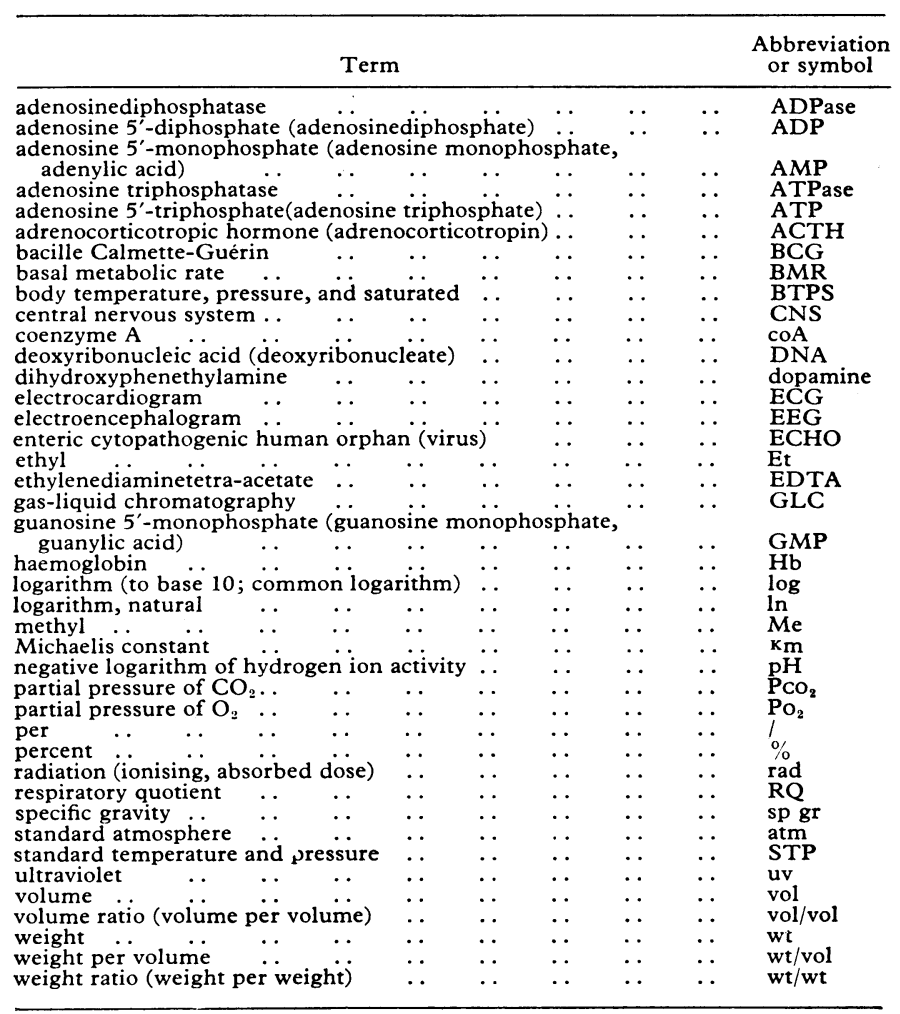

\section{Submission of manuscripts}

Mail the required number of manuscript copies in a heavypaper envelope, enclosing the manuscript copies and figures in cardboard, if necessary, to prevent bending of photographs during mail handling. Place photographs and transparencies in a separate heavy-paper envelope.
Manuscripts should be accompanied by a covering letter from the author who will be responsible for correspondence regarding the manuscript. The covering letter should contain a statement that the manuscript has been seen and approved by all authors. The letter should give any additional information that may be helpful to the editor, such as the type of article the manuscript represents in the particular journal, information on prior or duplicate publication or submission of any part of the work, and whether the author(s) will be willing to meet the cost of reproducing colour illustrations. Include copies of any permissions needed to reproduce published material or to use illustrations of identifiable subjects.

\section{Abbreviations of names of frequently cited journals and participating journals}

The journals listed below by abbreviated title are those covered by Abridged Index Medicus and additional journals participating in the Uniform Requirements agreement. Participating journals are marked by an asterisk.

Acta Paediatr Scand* Activox* AJR*

Am Fam Physician*

Am Heart J

Am J Cardiol*

Am J Clin Nutr*

Am J Clin Pathol

Am J Dis Child*

Am J Epidemiol*

Am J Hosp Pharm*

Am J Hum Genet*

Am J Med*

Am J Med Sci

Am J Nurs

Am J Obstet Gynecol

Am J Ophthalmol

Am J Pathol*

Am J Phys Med

Am J Psychiatry*

Am J Public Health*

Am J Surg*

Am J Trop Med Hyg

Am Rev Respir Dis*

Am Surg*

Anaesthesia*

Anaesth Intensive Care*

Anesth Analg (Cleve)*

Anesthesiology

Ann Clin Biochem*

Ann Clin Lab Sci*

Ann Intern Med*

Ann Otol Rhinol Laryngol*

Ann R Coll Phys Surg Can*

Ann R Coll Surg Engl*

Ann Rheum Dis*

Ann Surg*

Ann Thorac Surg*

Ann Trop Paediatr*

Arch Dermatol*

Arch Dis Child*

Arch Environ Health

Arch Gen Psychiatry*

Arch Intern Med*

Arch Invest Med (Mex)*

Arch Neurol*

Arch Ophthalmol*

Arch Otolaryngol*

Arch Pathol Lab Med*

Arch Phys Med Rehabil

Arch Surg*

Ariz Med*

Arteriosclerosis*

Arthritis Rheum

Aust Fam Physician*

Aust J Derm*

Aust J Hosp Pharm*

Aust J Ophthalmol*

Aust NZ J Med*

Aust NZ J Surg

Aust Paediatr J*
Bangladesh Paediatr*

Bibl Laeger

Blood

Bol Med Hosp Infant Mex

Bordeaux Med*

Brain

Brain Develop*

Br Dent J*

Br Heart J*

Br Homeopath J*

Br J Ind Med*

Br J Obstet Gynaecol

Br J Ophthalmol*

Br J Pain*

Br J Radiol

Br J Surg*

Br J Vener Dis*

Br Med J*

Bull Med Libr Assoc*

Bull WHO*

CA

Cancer

Can J Public Health*

Can J Surg*

Can Med Assoc J*

Cardiovasc Res*

Cephalalgia*

Chest*

Chron Dis Can*

Circulation*

Clin Chem Acta*

Clin Invest $\mathrm{Me}$

Clin Orthop

Clin Pediatr (Phila)*

Clin Pharmacol Ther

Clin Prevent Dent*

Clin Toxicol

Community Med *

Crit Care Med

Cuad Hosp Clin*

Curr Concepts Hyperten

Cardiovasc Dis*

Curr Probl Surg

Dan Med Bull*

Diabetes

Dig Dis Sci

DM

Drug Intell Clin Pharm*

Endocrinology

Eur Heart J*

Eur J Cancer*

Eur J Clin Invest*

Eur J Resp Dis*

Eur J Rheum Inflam*

Fam Med Teacher*

Fin Med J*

Gastroenterology*

Gastrointest Endosc*

Geriatrics*

Gut* 
Hawaii Med J*

Heart Lung

Hospitals

Hosp Pharm*

Hosp Pract

Iatriki*

Indian J Dermatol Venereol Leprol*

Int J Epidemiol*

Int J Pediatr Nephrol*

Int Rehab Med*

J Allergy Clin Immunol*

JAMA*

$\mathrm{J}$ Am Diet Assoc

J Bone Joint Surg (Am)

$\mathrm{J}$ Bone Joint Surg $(\mathrm{Br})$

J Cardiovasc Surg*

J Chronic Dis*

$\mathrm{J}$ Clin Endocrinol Metab

J Clin Gastroenterol*

J Clin Invest

J Clin Pathol*

J Epidemiol Community Health*

J Fac Med (Baghdad)*

J Fam Pract

J Gerontol

J Hong Kong Med Technol Assoc*

J Immunol

J Irish Coll Physicians Surg*

$\mathrm{J}$ Infect Dis

J Lab Clin Med*

J Laryngol Otol

J Manipul Physiol Therap*

J Matern Child Health*

J Med Ethics*

J Med Educ

J Med Genet*
J Natl Cancer Inst*

J Nephrol*

J Nerv Ment Dis

J Neurol Neurosurg Psychiatry*

J Neurosurg

J Nucl Med Technol*

J Nurs Adm

J Oral Surg

J Pediatr

J Psychosom Res*

J R Army Med Corps*

J R Coll Physicians Lond*

J R Col Surg Edinb*

J R Nav Med Ser*

J Thorac Cardiovasc Surg

Trauma

J Urol

J Vivekananda Inst Med Sci*

Lakartidningen*

Lancet*

Lepr Rev*

Malay J Pathol*

Matern Child Health*

Mayo Clin Proc

Med Care*

Med Clin (Barc)*

Med Clin North Am

Medicine (Baltimore)

Medicine (Oxford)*

Med J Aust*

Med Lab Sci*

Med Lett Drugs Ther

Med Pediatr Oncol*

Mt Sinai J Med*

N Carolina Med J*

N Doct*
Ned Tijdschr Geneeskd*

N Engl J Med*

Neurology (NY)*

Newfoundland Med Assoc J*

Niger Med J*

Nord Med*

No To Hattatsu*

Nurs Clin North Am

Nursing*

Nurs Outlook

Nurs Res

NZ Fam Physician*

NZ Med J*

NZ J Med Lab Technol*

Obstet Gynecol

Ophthalmology*

Orthop Clin North Am

Orthopt J Aust*

Otolaryngol Head Neck Surg*

Papua New Guinea Med J*

Pathology*

Pediatr Clin North Am

Pediatrics

Periton Dialys Bull*

Pharmacotherapy*

Physician Sports Med*

Phys Ther

Plast Reconstr Surg

PM*

Postgrad Doct-Africa*

Postgrad Doct-Asia*

Postgrad Doct-Middle East*

Postgrad Med*

Postgrad Med J*

Prog Cardiovasc Dis

Public Health*
Public Health Pap*

Public Health Rep

Quart J Med*

Radiol Clin North Am

Radiology*

Rev Esp Rheumatol*

Rev Med Chil*

Rev Med IMSS*

Rheumatol Rehabil

$S$ Afr Med J*

Scand J Respir Dis*

Sex Transm Dis*

South Med J*

Sri Lankan Fam Physician*

Surg Clin North Am

Surgery

Surg Gynecol Obstet

Swed Med J*

Thorax*

Thromb Haemost*

Tidsskr Nor Laegeforen*

Transfusion*

Trop Gastroenterol*

Ugeskr Laeger*

Ulster Med J*

Undersea Biomed Res*

Urol Clin North Am

Vet Radiol*

WHO Chron*

WHO Monogr Ser*

WHO Tech Rep Ser*

World Health Stat $\mathrm{Q}^{*}$

World Med J*

Yale J Biol Med*
What is the safest tranquilliser, and should tranquillisers be taken at sea?

Tranquillisers may be categorised as major and minor tranquillisers. The former are the neuroleptic drugs that have an antipsychotic action and are widely used to treat the symptoms of behavioural disturbances of psychotic illnesses. The choice of drug depends on the patient's symptoms and the diagnosis. I presume, however, that this question refers to minor tranquillisers used for their anxiolytic effect. It is clearly preferable for the patient to cope without drugs, and tranquillisers, when prescribed, should be a part (and not the whole) of the treatment programme, which may include support, counselling, psychotherapy, etc. If symptoms of anxiety are sufficiently serious to warrant treatment benzodiazepines are the drugs of choice. They reduce the subjective feelings and anxiety and tension and also the accompanying palpitations, sweating, tremor, etc. They are very safe, and their most frequent side effect is sedation, which gradually wears off as tolerance develops. Although it has been suggested that tolerance to the anxiolytic effect develops less swiftly, the long-term (more than two months) clinical effectiveness of benzodiazepines in treating anxiety is doubtful. Death from an overdose of benzodiazepine alone rarely occurs-an important safety consideration given the frequency of self-poisoning with psychotropic drugs. Psychological and physical dependence, similar to that caused by barbiturates and alcohol, can occur, and this is another reason for prescribing benzodiazepines only when absolutely necessary. Despite what the advertisements say, there is little to choose in terms of efficacy or safety between the benzodiazepines now in clinical use; though they may differ in their metabolism or elimination, their pharmacological effects are similar, as is the risk of dependence on them. So far as their use at sea is concerned, those working with the machinery of the ship should exercise the caution appropriate to the use of any sedative drug, which may impair fine sensory-motor co-ordination. Passengers should avoid the simultaneous use of other depressants of the central nervous system as they potentiate the effect of benzodiazepines; in this context alcohol and the use of antihistamines to prevent sea sickness should be specifically prohibited.-A H GHODSE, consultant psychiatrist, London.

National Institute on Drug Abuse. Monograph 33. Benzodiazepines: a review of research results. Rockville, Maryland: NIDA, 1980.

World Health Organisation. Fifth review of psychoactive substances for international control. Geneva: WHO, 1981

orld Health Organisation, Government of Finland, United Nations Fund for Drug Control Abuse. Public health problems and psychotropic substances. Repor of a seminar convened by the WHO, the Government
An apparently normal, healthy 9-year-old boy with normal eating habits and regular bowel action passes considerable amounts of offensive flatus, especially soon after rising in the morning. Examination results are negative. What advice should be given?

Human intestinal gas contains nitrogen, oxygen, carbon dioxide, hydrogen, and methane ${ }^{1}$; however, only about $40 \%$ of individuals produce methane. Production of methane in normal subjects depends on their ethnic origin and intake of substrate. ${ }^{2}$ Methane is probably produced in $75-80 \%$ of Nigerians ${ }^{3}$ but in only $24 \%$ of Orientals. ${ }^{2}$ Hydrogen is produced by fermentation of non-absorbed carbohydrate, commonly referred to as dietary fibre, by bacteria normally present in the colon. Non-absorbable carbohydrate is found predominantly in vegetables, particularly legumes. The hydrogen produced is rapidly converted to methane by direct reduction of carbon dioxide by methanogenic bacteria. An increased intake of fibre or bran supplements, particularly when first introduced, will cause an increase in the production of flatus. Methane may also be produced directly from several other subtrates, including products of lactose and sucrose fermentation that would be increased by malabsorption of sugar. This is found in children who have a deficiency of hydrolases, usually lactase and less often sucrase, in the gut. Intolerance to lactose is a common condition in subjects from many parts of the world, particularly Africa, Asia, and the Americas. ${ }^{4}$ In these people lactase activity declines after the weaning period. Gastrointestinal symptoms of intolerance to lactose include abdominal distension, borborygmi, flatus, and abdominal pain. Growth of these subjects is usually normal. A 9-year-old boy who has a normal growth velocity is unlikely to have disease. A stagnant loop, because of increased numbers of bacteria, can give rise to increased quantities of offensive flatus, but he would have other symptoms and signs. Intolerance to lactose should be excluded, particularly if he is from an ethnic group in whom lactase activity declines. Provided that he does not have an intolerance to disaccharide, the production of offensive flatus may be decreased by reducing his intake of dietary fibre or stopping bran supplements.-C A HUGHES, senior lecturer in paediatrics, Birmingham.

Levitt MD. Volume and composition of human intestinal gas determined by means of an intestinal washout technique. $N$ Engl 7 Med 1971;284:1374-8. itt P, De Bruijn KM, Beeching MF, Goldberg E, Blendis LM. Studies on breath methane: the effect of ethnic origins and Lactulose. Gut 1980;21:951-9. ${ }_{3}^{3}$ Cummings JH. Short chain fatty acids in the human colon. Gut 1981;22:763-79. eight ounces of milk in healthy lactose-intolerant teenagers. Pediatrics 1975 eight ounces 